\title{
Nocardiopsis sinuspersici sp. nov., isolated from sandy rhizospheric soil
}

\author{
Javad Hamedi, ${ }^{1}$ Fatemeh Mohammadipanah, ${ }^{1}$ Mathias von Jan, ${ }^{2}$ \\ Gabriele Pötter, ${ }^{2}$ Peter Schumann, ${ }^{2}$ Cathrin Spröer, ${ }^{2}$ Hans-Peter Klenk ${ }^{2}$ \\ and Reiner M. Kroppenstedt ${ }^{2}$
}

Correspondence Javad Hamedi jhamedi@ut.ac.ir

\author{
${ }^{1}$ Microbial Biotechnology Laboratory, Department of Microbiology, School of Biology, College of \\ Science, University of Tehran, 14155-6455, Tehran, Iran \\ ${ }^{2}$ DSMZ - Deutsche Sammlung von Mikroorganismen und Zellkulturen, Inhoffenstraße 7b, 38124 \\ Braunschweig, Germany
}

A polyphasic taxonomic study of a halotolerant bacterium, isolated from sandy rhizospheric soil in Sarbandar, Persian Gulf, Iran, revealed that strain $\mathrm{HM}^{\top}{ }^{\top}$ represents a novel species within the genus Nocardiopsis. Results of the 16S rRNA gene sequence comparison revealed that strain $\mathrm{HM}^{\top}{ }^{\top}$ clustered with strains of the genus Nocardiopsis, showing the highest degree of $16 \mathrm{~S}$ rRNA gene sequence similarity to Nocardiopsis quinghaiensis (99.2\%), Nocardiopsis aegyptia (98.5\%) and Nocardiopsis halotolerans (98.3\%). However, DNA-DNA hybridization studies with these type strains revealed less than $39.6 \%$ similarity. Rather than genotypic differences, there are some phenotypic discrepancies between strain $\mathrm{HM}^{\top}$ and closely related species of the genus Nocardiopsis. Main morphological and chemotaxonomical features of strain $\mathrm{HM}^{\top}$ include: (i) growth characteristics, i.e. the formation of a scant light-yellow to white aerial mycelium and the typical zig-zag form of the hyphae, which fragment during ageing into smooth rod-shaped spores; (ii) the presence of meso-diaminopimelic acid and glucose plus ribose in whole-cell hydrolysates; (iii) the presence of diphosphatidylglycerol, phosphatidylethanolamine, phosphatidylcholine and phosphatidylinositol, together with three unknown Nocardiopsis-specific phospholipids (close to diphosphatidylglycerol in position) in polar lipid extracts; (iv) the presence of the major menaquinones MK-10 $\left(\mathrm{H}_{0}\right)$, MK-10 $\left(\mathrm{H}_{2}\right)$ and MK-9 $\left(\mathrm{H}_{0}\right)$ in the non-polar fraction; (v) the presence of iso/anteiso-branched plus 10-methyl-branched fatty acids, showing the diagnostic combination for species of the genus Nocardiopsis of iso-16:0 (31.1\%), anteiso-17 : 0 (19.2\%), 10-methyl-17 : 0 (5.8\%) and tuberculostearic acid (8.8\%); and (vi) the absence of mycolic acids. Analysis of the $16 \mathrm{~S}$ rRNA gene sequence revealed that strain $\mathrm{HM}^{\top}$ represents a distinct taxon within the genus Nocardiopsis. Based upon genotypic and phenotypic differences from other members of the genus, a novel species, Nocardiopsis sinuspersici sp. nov., is proposed. The type strain is $\mathrm{HM}^{\top}\left(=\mathrm{UTMC} 00102^{\top}=\mathrm{DSM} 45277^{\top}=\right.$ CCUG $\left.57624^{\top}\right)$.
Originally, members of the genus Nocardiopsis were isolated from mildewed grain (Brocq-Rousseau, 1904), but the natural habitat of these species is soil (Meyer, 1976, 1989; Mishra et al., 1987a, b). Numerous studies have shown that Nocardiopsis strains are ubiquitously distributed in the environment (Kroppenstedt \& Evtushenko, 2006). At the time of writing, there were 28 species of the genus Nocardiopsis with validly published names. Many of these species prefer moderately alkaline conditions ( $\mathrm{pH}$ 8.5) (Kroppenstedt, 1992) and some grow better on media supplemented with sodium chloride. Nocardiopsis

The GenBank/EMBL/DDBJ accession number for the 16S rRNA gene sequence of strain $\mathrm{HM}^{\top}{ }^{\top}$ is EU410476. strains are frequently isolated from alkaline soils with high salt concentrations (Mikami et al., 1982; Al-Tai \& Ruan, 1994; Yassin et al., 1993), but they have also been isolated from clinical material (Yassin et al., 1997).

The aim of this study was to classify strain $\mathrm{HM}^{\mathrm{T}}$, a strain isolated from rhizospheric soil, by morphological, physiological, chemotaxonomic and molecular biological methods, and it is proposed that it represents a novel species of the genus Nocardiopsis.

Strain $\mathrm{HM}^{\mathrm{T}}$ was isolated from rhizospheric soil $(\mathrm{pH} 7.7$ and salinity $7.5 \%$ ) taken at a depth of $10 \mathrm{~cm}$ on the seashore of Sarbandar, Persian Gulf, southern Iran. The samples were air-dried (Nolan \& Cross, 1988), followed by heat-drying at 
$120{ }^{\circ} \mathrm{C}$ for $10 \mathrm{~min}$ (Nonomura \& Ohara, 1971a) and irradiating at $257 \mathrm{~nm}$ for $5 \mathrm{~min}$ (Galatenko \& Trekhova, 1990). The dried and irradiated samples were then treated with phenol $(1.5 \%)$ using the method of Hayakawa et al. (1991). Enrichment of the micro-organisms was carried out by using chitin as described by Williams et al. (1972). Isolation was carried out by the dilution plating method on GAC agar (Nonomura \& Ohara 1971b) supplemented with cycloheximide $\left(100 \mu \mathrm{g} \mathrm{ml}^{-1}\right)$ after 3 weeks of incubation at $28{ }^{\circ} \mathrm{C}$. Strains for comparison of physiological characteristics with $\mathrm{HM}^{\mathrm{T}}$ were obtained from Deutsche Sammlung von Mikroorganismen und Zellkulturen (DSMZ), Braunschweig, Germany. These strains were maintained on ISP2 agar slants at $4{ }^{\circ} \mathrm{C}$ and as $20 \%(w / v)$ glycerol suspensions at $-20{ }^{\circ} \mathrm{C}$.

Determination of morphological traits and colours of the aerial and substrate mycelium, as well as of soluble pigments, was performed as described by Shirling \& Gottlieb (1966). Mycelium colour was determined by comparing the culture with chips from ISCC-NBS colour charts (Kelly, 1964). The intact arrangement of hyphae, notably aerial hyphae and spore chains, was observed on ISP2 agar after 14 days at $28{ }^{\circ} \mathrm{C}$ by using the coverslip technique (Kawato \& Shinobu, 1959). Micromorphological characteristics of strain $\mathrm{HM}^{\mathrm{T}}$ were observed by using scanning electron microscopy (CEM902A, Zeiss).

On ISP2 medium, a sparse spore mass on a light yellow background was observed (Table 1). At the end of the hyphae, a zig-zag formation typical of members of the genus Nocardiopsis was observed. In older cultures, hyphae of aerial mycelium disintegrated into spore-like structures. During this process, the colour of colonies changed to dirty yellow. No pigments were released into any of the media tested. Vegetative hyphae were long, well-developed and fragmented during ageing. Long spore-chains were borne on the aerial hyphae. Spores $(0.4 \times 1.5 \mu \mathrm{m})$ were rodshaped and smooth-surfaced (Fig. 1). Strain $\mathrm{HM}^{\mathrm{T}}$ showed the typical macroscopic and microscopic appearance of most species of the genus Nocardiopsis (Meyer, 1976, 1989).

Assimilation of carbon sources at a final concentration of $1 \%(\mathrm{w} / \mathrm{v})$ was tested by using ISP 9 as the basal medium (Shirling \& Gottlieb, 1966). Utilization of nitrogen sources, decomposition of other organic compounds, degradation activity and enzymic activity were determined as described by Williams et al. (1983).
The strain was able to grow at $15-37{ }^{\circ} \mathrm{C}$ but not at 10 or $40{ }^{\circ} \mathrm{C}$. Optimum growth temperature was $28{ }^{\circ} \mathrm{C}$. Good growth could be obtained with 0 to $15 \% \mathrm{NaCl}$ but not in the presence of $17.5 \% \mathrm{NaCl}$. Optimum salt concentration for growth was $2.5 \%$. Strain $\mathrm{HM}^{\mathrm{T}}$ could grow well from $\mathrm{pH} 5$ to $\mathrm{pH} 12$ but not at $\mathrm{pH} 4$ or 13. Optimum $\mathrm{pH}$ for growth was 7 .

Biomass for chemical and molecular systematic studies was obtained by cultivation for 6 days in shake flasks (200 r.p.m.) using GYM broth (Shirling \& Gottlieb, 1966), pH 7.2 at $28{ }^{\circ} \mathrm{C}$. Cells were harvested by centrifugation and washed twice with deionized water. Analyses of amino acids and sugars were carried out by using the methods of Staneck \& Roberts (1974). Polar lipids and menaquinones were obtained from freeze-dried cells by using the integrated extraction method of Minnikin et al. (1984). Polar lipids were separated by TLC (Minnikin et al., 1984) and menaquinones were analysed by HPLC (Kroppenstedt, 1982, 1985). Fatty acids were converted into their corresponding methyl esters, extracted and analysed by gas-liquid chromatography according to the method of Sasser (1990).

Whole-cell hydrolysates of strain $\mathrm{HM}^{\mathrm{T}}$ contained mesodiaminopimelic acid and non-diagnostic sugars, including glucose and ribose. The diagnostic sugars arabinose, xylose and madurose were not detected. Therefore $\mathrm{HM}^{\mathrm{T}}$ is classified in cell-wall type III (Lechevalier \& Lechevalier, 1980). Strain $\mathrm{HM}^{\mathrm{T}}$ contained menaquinones in the following proportions: $48 \%$ MK-10(H0), $22 \%$ MK10(H2), $18 \%$ MK-9(H0), $7 \%$ MK-9(H2) and $6 \%$ MK10(H4). Analysis of the polar lipid extracts by TLC showed the diagnostic phospholipids phosphatidylcholine and phosphatidylethanolamine (phospholipid pattern type III, according to Lechevalier et al., 1977). Three phospholipid spots close to diphosphatidylglycerol, which is diagnostic for members of the genus Nocardiopsis, could be detected also, together with the non-diagnostic phosphatidylinositol, phosphatidylglycerol and some glycolipids of unknown structure (Kroppenstedt, 1992).

Phospholipid pattern matched quite well with those found in species of the genus Nocardiopsis (Kroppenstedt \& Evtushenko, 2006). The fatty acid pattern revealed mainly iso/anteiso-branched and 10-methyl-branched fatty acids. The principal fatty acids were iso-16:0 (31.1\%), anteiso-

Table 1. Cultural characteristics of strain $\mathrm{HM}^{\top}$

ISP, International Streptomyces Project (Shirling \& Gottlieb, 1966). Colours were taken from ISCC-NBS colour charts (Kelly, 1964).

\begin{tabular}{|llll|}
\hline Medium & Growth & Aerial mycelium & Substrate mycelium \\
\hline Yeast extract/malt extract agar (ISP 2) & Good & White/ light yellow & Yellow \\
Oatmeal agar (ISP 3) & Poor & Pale yellow & Pale yellow \\
Inorganic salts/starch agar (ISP 4) & Poor & White & Light yellow \\
Glycerol/asparagine agar (ISP 5) & Very poor & Pale yellow & Pale yellow \\
\hline
\end{tabular}




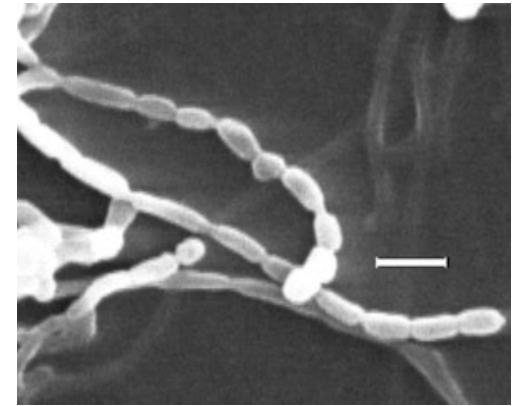

Fig. 1. Scanning electron micrograph of strain $\mathrm{HM}^{\top}$ after growth on ISP2 medium for 14 days at $28^{\circ} \mathrm{C}$. Bar, $2 \mu \mathrm{m}$.

$17: 0$ (19.2\%), 10-methyl-18: 0 (8.8\%),and 10-methyl-17:0 $(5.8 \%)$. The qualitative and quantitative composition of the fatty acid pattern is diagnostic for members of the genus Nocardiopsis (Kroppenstedt, 1985, 1992). All chemotaxonomic properties of strain $\mathrm{HM}^{\mathrm{T}}$ were consistent with its classification in the genus Nocardiopsis (Kroppenstedt \& Evtushenko, 2006). The DNA G $+\mathrm{C}$ base content of strain $\mathrm{HM}^{\mathrm{T}}$ was $71.6 \mathrm{~mol} \%$ by HPLC (Mesbah et al. 1989, Tamaoka \& Komagata 1984).

Genomic DNA was extracted by using a DNA extraction kit (JetFlex). PCR-mediated amplification of the 16S rRNA gene was performed by using the primers $10-30 \mathrm{~F}\left(5^{\prime}-\right.$ GAGTTTGATCCTGGCTCA-3') and 1500R (5'-AGAAAGGAGGTGATCCAGCC $-3^{\prime}$ ) as described by Rainey et al. 1996. Purification of PCR products was carried out by using a DNA purification kit (Qiagen).
Phylogenies were inferred by using the maximum-likelihood (Felsenstein, 1993), maximum-parsimony (Fitch, 1972) and neighbour-joining (Saitou \& Nei, 1987) clustering algorithms from the PHYLIP software package (Felsenstein, 1993). The resultant tree topologies were evaluated in a bootstrap analysis (Felsenstein, 1993) based on 1000 resamplings, using both the neighbour-joining and maximum-parsimony algorithms of the PHYLIP package (Felsenstein, 1993). The root position of the neighbourjoining tree was deduced by using Nocardiopsis trehalosi VKM Ac-942 as the outgroup.

Strain $\mathrm{HM6}^{\mathrm{T}}$ showed the highest degree of $16 \mathrm{~S}$ rRNA gene sequence similarity to members of the genus Nocardiopsis, especially to Nocardiopsis quinghaiensis (Chen et al., 2008) (99.2 \%), Nocardiopsis aegyptia (Sabry et al., 2004) (98.5\%) and Nocardiopsis halotolerans (Al-Zarban et al., 2002) (98.2\%). Fig. 2 shows a phylogenetic dendrogram displaying the relatedness of strain $\mathrm{HM}^{\mathrm{T}}$ to strains of the genus Nocardiopsis with the highest degree of sequence similarity ( $>97.4 \%$, according to Eztaxon), ignoring the less closely related type strains Nocardiopsis valliformis HBUM $20028^{\mathrm{T}}$, $N$. alkaliphila DSM $44657^{\mathrm{T}}$, N. listeri DSM $40297^{\mathrm{T}}, N$. composta $\mathrm{KS}^{\mathrm{T}}, N$. halophila KCTC $9825^{\mathrm{T}}, N$. baichengensis YIM $90130^{\mathrm{T}}, N$. rosea YIM $90094^{\mathrm{T}}, N$. gilva YIM $90087^{\mathrm{T}}, N$. arabia $\mathrm{S} 186^{\mathrm{T}}, N$. chromatogenes YIM $90109^{\mathrm{T}}$ and $N$. rhodophaea YIM $90096^{\mathrm{T}}$.

Strain $\mathrm{HM} 6^{\mathrm{T}}$ can be clearly distinguished from described species of the genus Nocardiopsis by the primary structure of the 16S rRNA genes. At this level of 16S rRNA gene relatedness, strain $\mathrm{HM}^{\mathrm{T}}$ and $\mathrm{N}$. aegyptia and $\mathrm{N}$. halotolerans belong to different DNA-DNA reassociation groups and should not be combined in a single species

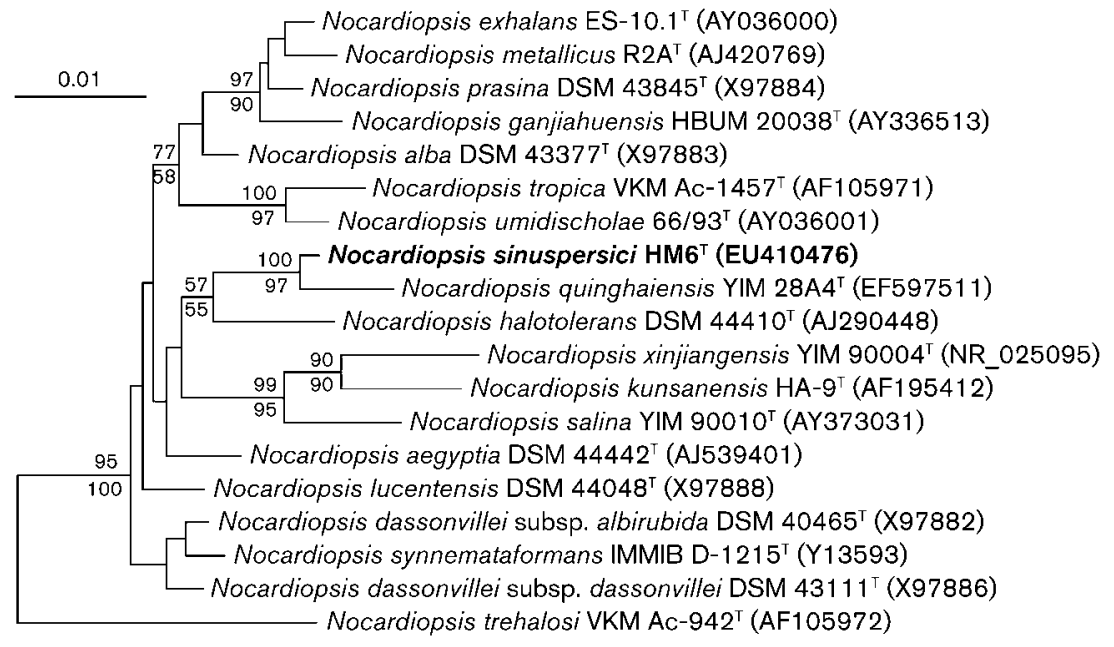

Fig. 2. Phylogenetic dendrogram based on $16 \mathrm{~S}$ rRNA gene sequence analysis, reconstructed from evolutionary distances by using the neighbour-joining method, showing the phylogenetic position of strain $\mathrm{HM}^{\top}$ and the most closely related species. Bootstrap values ( $>50 \%$; value above branch, neighbour-joining; value below branch, maximum-parsimony) are indicated at the relevant branching points. Bar, 0.01 substitutions per nucleotide position. 
(Stackebrandt \& Goebel, 1994; Stackebrandt \& Ebers, 2006). DNA-DNA hybridization analyses were performed between strain $\mathrm{HM}^{\mathrm{T}}$ and the three type strains showing the highest $16 \mathrm{~S}$ rRNA gene sequence similarity to $\mathrm{HM}^{\mathrm{T}}{ }^{\mathrm{T}}$.

DNA was isolated by using a French pressure cell (Thermo Spectronic) and was purified by chromatography on hydroxyapatite as described by Cashion et al. (1977). DNA-DNA hybridization was carried out as described by De Ley et al. (1970) under consideration of the modifications described by Huß et al. (1983) using a Cary 100 Bio UV/VIS-spectrophotometer equipped with a Peltier-thermostatted $6 \times 6$ multicell changer and a temperature controller with in-situ temperature probe (Varian).
Analysis of strain $\mathrm{HM}^{\mathrm{T}}$ revealed only low DNA-DNA reassociation of $39.6 \%$ with $N$. quinghaiensis DSM $44739^{\mathrm{T}}$, $30.7 \%$ with $N$. halotolerans DSM $44410^{\mathrm{T}}$ and $31.8 \%$ with N. aegyptia DSM $44442^{\mathrm{T}}$; values were far below the $70 \%$ suggested for strains of the same species (Wayne et al., 1987). Strain $\mathrm{HM}^{\mathrm{T}}$ differs from the type strains of $N$. quinghaiensis, N. aegyptia and N. halotolerans not only in its genotype but also in the phenotype (Table 2). Strain $\mathrm{HM}^{\mathrm{T}}$ can be differentiated from N. quinghaiensis DSM $44739^{\mathrm{T}}$ by physiological and chemotaxonomic characteristics (Table 2). Strain $\mathrm{HM}^{\mathrm{T}}$ can also be distinguished from $N$. quinghaiensis DSM $44739^{\mathrm{T}}$ by utilization of Dgalactose, melibiose, lactose, L-rhamnose, D-xylose, propionate, L-arabinose, inositol and allantoin. More impor-

Table 2. Diagnostic characteristics of strain $\mathrm{HM}^{\top}$ and species of the genus Nocardiopsis with closely related $16 \mathrm{~S}$ rRNA gene sequences

Strains: 1 , HM6 $6^{\mathrm{T}} ; 2$, N. quinghaiensis DSM44739 ${ }^{\mathrm{T}} ; 3$, N. aegyptia DSM $44442^{\mathrm{T}} ; 4$, N. halotolerans DSM $44410^{\mathrm{T}} ; 5$, N. lucentensis DSM $44048^{\mathrm{T}}\left(\right.$ data $^{2}$ for strains 1-5 from this study); 6, N. alba DSM $43377^{\mathrm{T}}$ (data from Yassin et al., 1997); 7, N. dassonvillei subsp. dassonvillei DSM 43111 ${ }^{\mathrm{T}}$ (Evtushenko et al., 2000; Kroppenstedt \& Evtushenko, 2006); 8, N. umidischolae DSM 44362 ${ }^{\mathrm{T}}$ (Peltola et al., 2001); 9, N. dassonvillei subsp. albirubida DSM $40465^{\mathrm{T}}$ (Evtushenko et al., 2000). +, Positive; -, negative; v, variable; ND, no data.

\begin{tabular}{|c|c|c|c|c|c|c|c|c|c|}
\hline Characteristic & 1 & 2 & 3 & 4 & 5 & 6 & 7 & 8 & 9 \\
\hline Aerial mycelium & $\begin{array}{c}\text { White/ light } \\
\text { yellow }\end{array}$ & $\begin{array}{l}\text { White/ } \\
\text { yellowish }\end{array}$ & $\begin{array}{l}\text { White/ } \\
\text { yellowish }\end{array}$ & White/ yellow & White & White & $\begin{array}{c}\text { Greyish- } \\
\text { yellow }\end{array}$ & White & White \\
\hline \multicolumn{10}{|l|}{ Utilization of: } \\
\hline D-Galactose & + & - & + & + & - & - & + & + & + \\
\hline L-Arabinose & - & + & + & - & - & - & + & + & + \\
\hline Melibiose & + & - & + & + & - & - & - & + & - \\
\hline Adonitol & - & - & $\mathrm{ND}$ & - & - & - & - & - & - \\
\hline Glycerol & + & + & + & + & + & + & + & $\mathrm{ND}$ & + \\
\hline Inositol & - & + & + & - & + & - & - & - & - \\
\hline Sucrose & + & + & + & + & + & + & + & + & - \\
\hline Ribose & - & - & - & - & - & $\mathrm{ND}$ & + & + & ND \\
\hline Lactose & + & - & + & - & - & - & - & + & - \\
\hline Mannitol & + & + & + & - & + & + & + & + & + \\
\hline D-Mannose & + & + & + & + & + & - & - & + & + \\
\hline L-Rhamnose & + & - & + & - & + & - & + & + & + \\
\hline D-Xylose & + & - & + & - & - & - & + & + & + \\
\hline Raffinose & - & - & - & - & + & - & - & $\mathrm{ND}$ & - \\
\hline Adenine & + & + & - & - & + & + & + & $\mathrm{ND}$ & + \\
\hline Gluconate & - & - & - & - & + & + & + & + & + \\
\hline Propionate & + & - & + & - & + & + & - & + & - \\
\hline Allantoin & - & + & + & - & - & $\mathrm{ND}$ & $\mathrm{ND}$ & $\mathrm{ND}$ & ND \\
\hline Tyrosine & + & + & + & + & + & + & + & $\mathrm{ND}$ & + \\
\hline Valine & + & + & + & + & - & $\mathrm{ND}$ & $\mathrm{ND}$ & $\mathrm{ND}$ & ND \\
\hline \multicolumn{10}{|l|}{ Growth at: } \\
\hline $10{ }^{\circ} \mathrm{C}$ & - & + & + & + & + & - & $\mathrm{v}$ & + & - \\
\hline $40{ }^{\circ} \mathrm{C}$ & - & - & - & - & - & - & - & $\mathrm{ND}$ & + \\
\hline $5 \% \mathrm{NaCl}$ & + & + & - & + & + & - & + & + & + \\
\hline $10 \% \mathrm{NaCl}$ & + & + & - & + & + & - & + & - & + \\
\hline $15 \% \mathrm{NaCl}$ & + & - & - & + & - & - & - & - & ND \\
\hline pH 12 & + & - & + & - & - & ND & $\mathrm{ND}$ & $\mathrm{ND}$ & ND \\
\hline $\begin{array}{l}\text { Major } \\
\text { menaquinones }\end{array}$ & $\begin{array}{c}10,10 / 2,9,9 / 2 \\
10 / 4\end{array}$ & $\begin{array}{c}10,10 / 2 \\
11 / 2,11,9 / 4\end{array}$ & $10 / 6,10 / 8$ & $10 / 0,10 / 2$ & $10 / 6,10 / 8$ & $10 / 4,10 / 6$ & $10 / 4,10 / 6$ & $\begin{array}{r}10 / 6,10 / 4 \\
10 / 8,11 / 8\end{array}$ & $10 / 0$ \\
\hline
\end{tabular}

${ }^{\star}$ Menaquinones abbreviated e.g. 10/4, MK-10(H4). 
tantly, strain $\mathrm{HM}^{\mathrm{T}}$ shows differences in growth at $10{ }^{\circ} \mathrm{C}$, $15 \% \mathrm{NaCl}$ and $\mathrm{pH} 12$ compared with $N$. quinghaiensis DSM $44739^{\mathrm{T}}$, N. aegyptia DSM $44442^{\mathrm{T}}$ and N. halotolerans DSM $44410^{\mathrm{T}}$. Also, from a chemotaxonomical point of view, it has differences in whole-cell sugars, phospholipid pattern, major menaquinones and predominant fatty acids (Table 3) compared with N. quinghaiensis DSM $44739^{\mathrm{T}}, N$. aegyptia DSM $44442^{\mathrm{T}}$ and $N$. halotolerans DSM $44410^{\mathrm{T}}$. Therefore, we consider strain $\mathrm{HM}^{\mathrm{T}}$ to represent a novel species of the genus Nocardiopsis, for which we propose the name Nocardiopsis sinuspersici sp. nov.

\section{Description of Nocardiopsis sinuspersici sp. nov.}

Nocardiopsis sinuspersici (si.nus.per'si.ci. L. masc. n. sinus persicus the Persian Gulf, sinuspersici L. gen. n. from the Persian Gulf, referring to where the type strain was isolated).

Aerobic, Gram-stain-positive actinomycete. Grows well on yeast extract/malt extract agar but only scant growth appears on oatmeal agar and inorganic salts/starch agar. Colour of the spore mass changes from white to dirtyyellow during ageing. No soluble pigments are produced. At the end of the straight substrate and aerial hyphae, a zigzag formation typical to the genus Nocardiopsis is observed. These structures disintegrate into spore-like elements during ageing. Hydrolyses casein and starch but not

Table 3. Cellular fatty acid composition (\%) of strain $\mathrm{HM}^{\top}$ and type strains of closely related species

Strains: $1, \mathrm{HM}^{\mathrm{T}} ; 2$, Nocardiopsis quinghaiensis DSM $44739^{\mathrm{T}}$ (data from Chen et al., 2008); 3, Nocardiopsis aegyptia DSM $44442^{\mathrm{T}}$ (Sabry et al., 2004); 4, Nocardiopsis halotolerans DSM 44410 ${ }^{\mathrm{T}}$ (Al-Zarban et al., 2002); 5, Nocardiopsis lucentensis DSM $44048^{\mathrm{T}}$ (Yassin et al., 1993). -, Not present.

\begin{tabular}{|lccccc|}
\hline Fatty acids & $\mathbf{1}$ & $\mathbf{2}$ & $\mathbf{3}$ & $\mathbf{4}$ & $\mathbf{5}$ \\
\hline iso-14:0 & 2.5 & 5.6 & 12.1 & 2.4 & 1.0 \\
iso-15:0 & 0.7 & 2.6 & 1.7 & 3.4 & 5.2 \\
anteiso-15:0 & 6.7 & 14.6 & 6.5 & 16.7 & 12.6 \\
$15: 0$ & - & - & - & 0.7 & 1.2 \\
iso-16:0 & 31.1 & 30.0 & 19.1 & 23.3 & 18.7 \\
$16: 0$ & 0.6 & 3.7 & 4.2 & 3.2 & 3.8 \\
$10-$ Methyl-16:0 & 0.7 & 1.8 & 1.5 & - & 1.2 \\
$16: 1$ & 0.3 & - & 1.1 & 1.3 & 1.5 \\
iso-16:1 & - & 7.5 & - & - & - \\
iso-17:0 & 2.1 & 2.2 & 5.1 & 4.2 & 30.5 \\
anteiso-17:0 & 19.2 & 10.0 & 17.9 & 18.7 & 14.5 \\
$17: 0$ & 2.0 & 2.8 & 1.3 & 3.1 & 3.3 \\
$17: 1$ & 1.6 & 2.7 & 1.7 & 6.8 & 2.6 \\
anteiso-17: 1 & 0.4 & - & 1.4 & - & - \\
$10-$ Methyl-17:0 & 5.8 & 2.8 & 2.6 & 6.6 & 2.8 \\
iso-18:0 & 4.2 & 1.4 & 3.2 & 1.3 & 1.4 \\
$18: 0$ & 6.0 & 4.5 & 7.3 & 3.5 & 2.5 \\
$18: 1$ & 3.3 & 4.6 & 7.8 & 8.5 & 1.7 \\
$10-$ Methyl-18:0 & 8.8 & 4.5 & 12.2 & 1.3 & 1.5 \\
& & & & & \\
\hline
\end{tabular}

adenine, lecithin and pectin. Nitrate is reduced to nitrite. $\mathrm{H}_{2} \mathrm{~S}$, melanin and urease are not produced. D-Galactose, lactose, melibiose, glycerol, sucrose, maltose, mannitol, D-mannose, L-rhamnose, D-xylose, inulin, citrate, malonate, pyruvate and propionate are used as sole carbon sources, whereas L-arabinose, fructose, adonitol, inositol, ribose, raffinose, gluconate, sorbitol and allantoin cannot be used. L-Alanine, L-asparagine, L-histidine, L-proline, Larginine, L-serine, L-valine, L-phenylalanine, L-lysine and Ltyrosine can be utilized as sole nitrogen sources, whereas Lcystine, L-ornithine and L-tryptophan cannot. Grows at 15$37{ }^{\circ} \mathrm{C}$ (optimum $28{ }^{\circ} \mathrm{C}$ ), pH 5-12 (optimum pH 7) and 0$15 \% \mathrm{NaCl}$ (optimum $2.5 \%$ ). The fatty acid profile includes iso- $16: 0$, anteiso- $17: 0,10$-methyl-18:0, anteiso- $15: 0$, $18: 0,10$-methyl- $17: 0$, iso- $18: 0$, cis- $918: 1$, iso- $14: 0$, iso$17: 0,17: 0$ and cis-9 $17: 1$. Whole-cell hydrolysates contain meso-diaminopimelic acid and the non-diagnostic sugars glucose and ribose. The principal menaquinones are MK$10\left(\mathrm{H}_{0}\right)$, MK-10 $\left(\mathrm{H}_{2}\right)$ and MK-9 $\left(\mathrm{H}_{0}\right)$; however, MK-9 $\left(\mathrm{H}_{2}\right)$ and MK-10 $\left(\mathrm{H}_{4}\right)$ are also present. The DNA G $+\mathrm{C}$ content of the type strain is $71.6 \mathrm{~mol} \%$. Polar lipids are phosphatidylglycerol, phosphatidylethanolamine, phosphatidylcholine and phosphatidylinositol together with three unknown phospholipids located above diphosphatidylglycerol, which is diagnostic for members of the genus Nocardiopsis. Mycolic acids are absent.

The type strain is $\mathrm{HM}^{\mathrm{T}}\left(=\mathrm{UTMC} 00102^{\mathrm{T}}=\mathrm{DSM} 45277^{\mathrm{T}}\right.$ $=$ CCUG $57624^{\mathrm{T}}$ ) isolated from rhizospheric soil taken at a depth of $10 \mathrm{~cm}$ on the seashore of the Persian Gulf, Sarbandar, southern Iran.

\section{Acknowledgements}

The authors would like to thank Evelyne Brambilla, Birgit Grün and Marlen Jando for technical assistance.

\section{References}

Al-Tai, A. M. \& Ruan, J. S. (1994). Nocardiopsis halophila sp. nov., a new halophilic actinomycete isolated from soil. Int J Syst Bacteriol 44, 474-478.

Al-Zarban, S. S., Abbas, I., Al-Musallam, A. A., Steiner, U., Stackebrandt, E. \& Kroppenstedt, R. M. (2002). Nocardiopsis halotolerans sp. nov., isolated from salt marsh soil in Kuwait. Int $J$ Syst Evol Microbiol 52, 525-529.

Brocq-Rousseau, D. (1904). Sur un Streptothrix. Ref Gen Botanique 16, 219-230.

Cashion, P., Holder-Franklin, M. A., McCully, J. \& Franklin, M. (1977). A rapid method for base ratio determination of bacterial DNA. Anal Biochem 81, 461-466.

Chen, Y.-G., Cui, X.-L., Kroppenstedt, R. M., Stackebrandt, E., Wen, M.-L., Xu, L.-H. \& Jiang, C.-L. (2008). Nocardiopsis quinghaiensis sp. nov., isolated from saline soil in China. Int J Syst Evol Microbiol 58, 699-705.

De Ley, J., Cattoir, H. \& Reynaerts, A. (1970). The quantitative measurement of DNA hybridization from renaturation rates. Eur $J$ Biochem 12, 133-142. 
Evtushenko, L. I., Taran, V. V., Akimov, V. N., Kroppenstedt, R. M., Tiedje, J. M. \& Stackebrandt, E. (2000). Nocardiopsis tropica sp. nov., Nocardiopsis trehalosi sp. nov., nom. rev. and Nocardiopsis dassonvillei subsp. albirubida subsp. nov., comb. nov. Int J Syst Evol Microbiol 50, 73-81.

Felsenstein, J. (1993). PHYLIP (phylogeny inference package) version 3.5.1. Distributed by the author. Department of Genome Sciences, University of Washington, Seattle, USA.

Fitch, W. M. (1972). Toward defining the course of evolution: minimum change for a specific tree topology. Syst Zool 20, 406-416.

Galatenko, O. A. \& Trekhova, L. P. (1990). Isolation of antibiotic producing actinomycetes from soil samples exposed to UV light. Antibiot Khimioter 35, 6-8. (in Russian)

Hayakawa, M., Kajiura, T. \& Nonomura, H. (1991). New Methods for the highly selective isolation of Streptosporangium and Dactylosporangium from soil. J Ferment Bioeng 72, 327-333.

Huß, V. A. R., Festl, H. \& Schleifer, K. H. (1983). Studies on the spectrophotometric determination of DNA hybridization from renaturation rates. Syst Appl Microbiol 4, 184-192.

Kawato, N. \& Shinobu, R. (1959). On Streptomyces herbaricolor sp. nov., supplement: a single technique for microscopical observation. Mem Osaka Univ Lib Arts Educ B 8, 114-119.

Kelly, K. L. (1964). Inter-Society Color Council - National Bureau of Standards Color Name Charts Illustrated with Centroid Colors. Washington, DC: US Government Printing Office.

Kroppenstedt, R. M. (1982). Separation of bacterial menaquinones by HPLC using reverse phase (RP18) and a silver loaded ion exchanger as stationary phases. J Liq Chromatogr 5, 2359-2367.

Kroppenstedt, R. M. (1985). Fatty acid and menaquinone analysis of actinomycetes and related organisms. In Chemical Methods in Bacterial Systematics (Society for Applied Bacteriology Technical Series vol. 20), pp. 173-199. Edited by M. Goodfellow \& D. E. Minnikin. New York: Academic Press.

Kroppenstedt, R. M. (1992). The genus Nocardiopsis. In The Prokaryotes, 2nd edn, pp. 1139-1156. Edited by A. Balows, H. G. Trüper, M. Dworkin, W. Harder \& K.-H. Schleifer. New York: Springer.

Kroppenstedt, R. M. \& Evtushenko, L. I. (2006) The family Nocardiopsaceae. In The Prokaryotes: a Handbook on the Biology of Bacteria, 3rd edn, vol 3, pp. 754-795. Edited by M. Dworkin, S. Falkow, E. Rosenberg, K.-H. Schleifer \& E. Stackebrandt.

Lechevalier, M. P. \& Lechevalier, H. A. (1980). The chemotaxonomy of actinomycetes. In Actinomycete Taxonomy (Special Publication no. 6), pp. 227-291. Edited by A. Dietz \& D. W. Thayer. Arlington, VA: Society for Industrial Microbiology.

Lechevalier, M. P., De Bièvre, C. \& Lechevalier, H. A. (1977), Chemotaxonomy of aerobic actinomycetes: phospholipid composition. Biochem Syst Ecol 5, 249-260.

Mesbah, M., Premachandran, U. \& Whitman, W. B. (1989). Precise measurement of the $\mathrm{G}+\mathrm{C}$ content of deoxyribonucleic acid by high performance liquid chromatography. Int J Syst Bacteriol 39, 159-167.

Meyer, J. (1976). Nocardiopsis, a new genus of the order Actinomycetales. Int J Syst Bacteriol 26, 487-493.

Meyer, J. (1989). Genus Nocardiopsis Meyer 1976, 487 ${ }^{\mathrm{AL}}$. In Bergey's Manual of Systematic Bacteriology, vol. 4, pp. 2562-2569. Edited by S. T. Williams, M. E. Sharpe \& J. G. Holt. Baltimore: Williams \& Wilkins.

Mikami, Y., Miyashita, K. \& Arai, T. (1982). Diaminopimelic acid profiles of alkalophilic and alkaline-resistant strains of actinomycetes. J Gen Microbiol 128, 1709-1712.

Minnikin, D. E., O'Donnell, A. G., Goodfellow, M., Alderson, G., Athalye, M., Schaal, A. \& Parlett, J. H. (1984). An integrated procedure for the extraction of bacterial isoprenoid quinones and polar lipids. J Microbiol Methods 2, 233-241.

Mishra, S. K., Keller, J. E., Miller, J. R., Heisey, R. M., Nair, M. G. \& Putnam, A. R. (1987a). Insecticidal and nematicidal properties of microbial metabolites. J Ind Microbiol 2, 267-276.

Mishra, S. K., Traft, W. H., Putnam, A. R. \& Ries, S. K. (1987b). Plant growth regulatory metabolites from novel actinomycetes. J Plant Growth Regul 6, 75-84.

Nolan, R. D. \& Cross, T. (1988). Isolation and screening of actinomycetes. In Actinomycetes in Biotechnology, pp. 2-8. Edited by M. Goodfellow, S. T. Williams \& M. Mordarski. London: Academic Press.

Nonomura, H. \& Ohara, Y. (1971a). Distribution of actinomycetes in soil. X. New genus and species of monosporic actinomycetes. J Ferment Technol 49, 895-903.

Nonomura, H. \& Ohara, Y. (1971b). Distribution of actinomycetes in soil. XI. Some new species of the genus Actinomadura Lechevalier et al. J Ferment Technol 49, 904-912.

Peltola, J. S. P., Anderson, M. A., Kämpfer, P., Auling, G., Kroppenstedt, R. M., Busse, H.-J., Salkinoja-Salonen, M. S. \& Rainey, F. A. (2001). Isolation of toxigenic Nocardiopsis strains from indoor environments and description of two new Nocardiopsis species; $N$. exhalans sp. nov. and N. umidischolae sp. nov. Appl Environ Microbiol 67, 4293-4304.

Rainey, F. A., Ward-Rainey, N., Kroppenstedt, R. M. \& Stackebrandt, E. (1996). The genus Nocardiopsis represents a phylogenetically coherent taxon and a distinct actinomycete lineage: proposal of Nocardiopsaceae fam. nov. Int J Syst Bacteriol 46, 1088-1092.

Sabry, S. A., Ghanem, N. B., Abu-Ella, G. A., Schumann, P., Stackebrandt, E. \& Kroppenstedt, R. M. (2004). Nocardiopsis aegyptia sp. nov., isolated from marine sediment. Int J Syst Microbiol 54, 453456.

Saitou, N. \& Nei, M. (1987). The neighbor-joining method: a new method for reconstructing phylogenetic trees. Mol Biol Evol 4, 406425.

Sasser, M. (1990). Identification of bacteria by gas chromatography of cellular fatty acids, MIDI Technical Note 101. Newark, DE: MIDI Inc.

Shirling, E. B. \& Gottlieb, D. (1966). Methods for characterization of Streptomyces species. Int J Syst Bacteriol 16, 313-340.

Stackebrandt, E. \& Ebers, J. (2006). Taxonomic parameters revisited: tarnished gold standards. Microbiol Today 33, 152-155.

Stackebrandt, E. \& Goebel, B. M. (1994). Taxonomic note: a place for DNA-DNA reassociation and $16 \mathrm{~S}$ rRNA sequence analysis in the present species definition in bacteriology. Int J Syst Bacteriol 44, 846849.

Staneck, J. L. \& Roberts, G. D. (1974). Simplified approach to the identification of aerobic actinomycetes by thin-layer chromatography. Appl Microbiol 28, 226-231.

Tamaoka, J. \& Komagata, K. (1984). Determination of DNA base composition by reversed-phase high-performance liquid chromatography. FEMS Microbiol Lett 25, 125-128.

Wayne, L. G., Brenner, D. J., Colwell, R. R., Grimont, P. A. D., Kandler, O., Krichevsky, M. I., Moore, L. H., Moore, W. E. C., Murray, R. G. E. \& other authors (1987). International Committee on Systematic Bacteriology. Report of the ad hoc committee on reconciliation of approaches to bacterial systematics. Int J Syst Bacteriol 37, 463464.

Williams, S. T., Shameemullah, M., Watson, E. T. \& Mayfield, C. I. (1972). Studies on the ecology of actinomycetes in soil. VI. The influence of moisture tension on growth and survival. Soil Biol Biochem 4, 215-225. 
Williams, S. T., Goodfellow, M., Alderson, G., Wellington, E. M. H., Sneath, P. H. A. \& Sackin, M. J. (1983). Numerical classification of Streptomyces and related taxa. J Gen Microbiol 129, 17431813.

Yassin, A. F., Galinski, E. A., Wohlfarth, A., Jahnke, K.-D., Schaal, K. P. \& Trüper, H. G. (1993). A new actinomycete species, Nocardiopsis lucentensis sp. nov. Int J Syst Bacteriol 43, 266-271.
Yassin, A. F., Rainey, F. A., Burghardt, J., Gierth, D., Ungerechts, J., Lux, I., Seifert, P., Bal, C. \& Schaal, K. P. (1997). Description of Nocardiopsis synnemataformans sp. nov., elevation of Nocardiopsis alba subsp. prasina to Nocardiopsis prasina comb. nov., and designation of Nocardiopsis antarctica and Nocardiopsis alborubida as later subjective synonyms of Nocardiopsis dassonvillei. Int J Syst Bacteriol 47, 983-988. 